\title{
Democratic and Inclusive Education in Iceland: Transgression and the Medical Gaze
}

\author{
Ólafur Páll Jónsson \\ School of Education \\ University of Iceland, \\ Email: opi@hi.is
}

\begin{abstract}
'Inclusive education' and 'democracy' are more than buzzwords in education. They refer to official educational policy in much of the western world. Democracy as a school policy seems to be widely accepted while inclusive education is more controversial, sometimes fuelling lively public debates where parents and politicians are vocal. However, there seems to be little agreement on what 'inclusive education' means, although one can discern a certain core to the understanding of 'inclusive education' among many of those who participate in the public debate. Central to the above understanding of inclusive education and democracy are certain features that I want to draw attention to. First, what falls under the headings 'democracy in schools', 'democratic education' or 'student democracy', on the one hand, and 'inclusive education', on the other, have little to do with one another. I discuss how the medical gaze in the context of education belongs to the dominant ideology of the time and is thus prevailing without ever having to be argued for or defended. The consequence of this is, as I see it, that education (which sometimes is more training than growth) is being cast in pathological terms. I connect the idea of transgression to that of democratic school and character. Transgression is relevant in two ways here. The school has to be a place where transgression is encouraged and, secondly, it is a place where transgression is valued as a democratic virtue. Virtue here could, I think, be understood in Aristotelian terms - or even given a Socratic interpretation.
\end{abstract}

Keywords: Inclusion, medical gaze, transgression, democratic education, Dewey, Foucault, Iceland

\section{Introduction}

In this article, I look at democratic and inclusive education in Iceland since the mid-1970s when important educational reforms took place. These changes marked the beginning of democratic and inclusive education as official educational policy (section 1). However, in the 1990s there was a backlash in this development as many of the democratic principles from the 1970s were abandoned for a more managerial system of education (section 2). The changes during the 1990s were not simply changes of policy but reflected underlying 
ideological differences concerning schools and education in general (section 3). I use Foucault's notion of the 'medical gaze' to reflect on these ideological differences (section 4). I then turn to inclusion and democracy as a task for schools and go into some details about democratic education, drawing on Foucault's notion of transgression and John Dewey's conception of democracy (sections 5 and 6). Finally, I conclude by arguing that inclusive, democratic education has to be a branch of character education backed by institutional commitment to students as moral subjects and not only as objects for formation.

\title{
1. Inclusion and democracy in Icelandic schools - the beginning
}

'Inclusive education' and 'democratic education' refer to official educational policy in Iceland that can be traced back to the School Act of 1974, when the primary objective of compulsory education became the preparation of students for life and work in an ever changing democratic society. Although the word 'inclusion' did not appear until 20 years later, the 1974 School Act had clear implications in the direction of inclusion.

Whilst the 1946 Education Act shifted the main focus from school subjects to the students' needs, it was the 1974 Education Act that recognized in law for the first time that all children of a given age had an equal right to education in the state school system and that the school had a role in meeting the full diversity of student needs ... The view that this should be done in the child's neighbourhood school rather than as a segregated provision has been stated since then in an increasingly unequivocal fashion by those who formulate official education policy. (Bjarnason \& Marinósson, 2015, p. 281)

The School Act of 1974, and the subsequent national curriculum for elementary schools (ages 7 to 16), was in many ways revolutionary, not only for the explicit statement of democracy and demand for more inclusive schools, but also for the extensive work on curricular design, teacher training, writing of new educational material, and so forth (Edelstein, 2013; Jónsson, 2014). Ingólfur Ásgeir Jóhannesson (2006) describes the changes in the following way:

\begin{abstract}
If we look at late twentieth-century educational history in Iceland from this perspective, we see that the reform efforts of the 1970s and 1980s were aimed at modernizing the Icelandic education system, with an emphasis on primary education (6 to 16 years). The reform was based on childcentred, humanistic, and egalitarian views which I will call the democratic principle. These views are apparent in cooperative learning methods, integration of subject matter, evaluation as process rather than product, and many other 'progressive' views in education. (p. 105)
\end{abstract}

Following the School Act of 1974 much work was devoted to putting these progressive views into practice under the leadership of Wolfgang Edelstein, though with more emphasis on democracy than inclusion. However, during the dark months of the Icelandic winter in 1983 to 1984 a new minister of education brought that work to a halt after fierce debate about the fate of history teaching in elementary schools.

Despite the great controversies surrounding this progressive work, democracy as a school policy was widely accepted, and although changes in the 1990s were in important ways antagonistic to the democratic principles from the 1970s, 
those principles have hardly ever been explicitly challenged in public discourse. The same cannot be said about inclusive education which has been more controversial, sometimes fuelling lively public debates among parents and politicians as well as scholars and teachers.

\title{
2. Discursive patterns
}

The term 'inclusive education' - or the clumsy Icelandic correlate 'school without differentiation' - came to Iceland with a translation of the Salamanca Statement in 1995, which the Ministry of Education sent to every school (Bjarnason \& Marinósson, 2015). However, the messages from the ministry and municipalities were far from unequivocal, as Bjarnason and Marinósson have observed:

\begin{abstract}
As a whole the Act from 2008 emphasizes equity, equal opportunities and an appropriate education for all children, irrespective of their physical, mental or sensory capacities, their socio-economic situation, national/ethnic origin or linguistic competences. But [in] the article on specialized services and support system for schools the emphasis is on increase in diagnostic psychological services in place of pedagogic or therapeutic work. Students should be evaluated from the first year of schooling to secure them appropriate teaching and support. Further, students who may have psychological or social problems, affecting their learning are entitled to diagnostic services, if the parents agree. (Bjarnason \& Marinósson, 2015, p. 140)
\end{abstract}

In the public debate on inclusive education, beginning in the 1990s when it became official educational policy, one can discern certain understandings or discursive patterns of both the role of schools in general and their 'proper role' for inclusion in particular. Although these patterns are reflected in some of the policy documents that came from the Ministry of Education in the 1990s (Jóhannesson, 2006; Bjarnason \& Marinósson, 2015), they do not form an explicitly stated and defended view of inclusive education, but figure rather as an ideological background to many of the claims about schools, teachers, students, and educational practices in general that are made in the public debate, as well as in various official policy documents. I shall label four distinct but interwoven themes.

(1) Individualistic understanding: Difficulties that students face are usually viewed as their difficulties, although those difficulties often result in problems for teachers and schools as well as the families of the students. The source of the difficulty is located in the individual students and the remedies proposed focus primarily on the individuals. Likewise, much of the demand for support is premised on individualized learning and the rights of the students which are, as discourses on rights usually are, very much individualistic (Jóhannesson, 2006).

(2) Medical model: Much of the discussion of inclusive education operates not only with a vocabulary of various individualistic learning difficulties (as in (1) above), but also from such a vocabulary, emphasizing mental and physical defects along with emotional disturbances. The difficulties are the starting points, often in the form a diagnosis, and the means taken are seen as remedies for whatever defect has been detected. In 2012, 16 per cent of the total elementary student population in Iceland had some formal diagnoses and in the east, where the number was highest, it was 24 per cent (Menntavísindastofnun Háskóla Íslands, 2014, p. 20). Accordingly, educational practices take the form 
of special education rather than inclusive education, revolving around diagnosis and fixing whatever is found to be out of order.

(3) Technical approach: To address the problems which are the concern of special education - rather than inclusive education - appropriate methods or techniques are called for. Jóhannesson puts it very succinctly when writing, 'Diagnosis rather than pedagogy appears as the method (technology) for inclusion' (Jóhannesson, 2006, p. 111). This is only to be expected, given the medical view of learning difficulties, but it has at the same time resulted in an increased drive towards diagnosis which has generated an overload of demands at The State Diagnostic and Counselling Centre. A technological view of education is also manifest in higher education, although not rooted in diagnostic practices as in primary and secondary education. Reflecting on the Bologna Process for higher education in Europe, Ronald Barnett (2003) remarks that '... in this discursive shift, in this reduction of curriculum or specifications largely of skills, we see a framing of the curriculum in instrumental terms. A curriculum is nothing but the production of a set of skills, and is only to be valued providing it delivers skills' (p. 564).

(4) Market-commodity view of education: All this is then set against a background condition of schools where students compete with each other for rank and opportunity - and where the schools themselves (from primary schools to universities) compete with each other for rank and funding - in an environment where education is by and large seen as any other market commodity. Education, especially at the upper secondary and university levels but also to some extent at the lower levels, is talked about as an investment and the students are said to increase their own market value by obtaining education. Although the market-commodity view of education may not be as entrenched in Iceland as in the US (Molnar, 2005), it has become a dominant view in much of the educational discourse (Jóhannesson, 2006), not least since 2013 when the Independence Party took over the Ministry of Education from the Left-Green Movement.

One can discern somewhat similar discursive patterns or underlying ideas relating to democracy in education. Individual preferences are taken to be the ultimate unit of analysis, democracy is thought of as a means for advancing such preferences (thus 'technical'), and its basic function is to regulate a free competition of individual opinions and preferences (thus the 'market-commodity view').

Public understanding of democracy as an educational ideal may, however, show itself more in what is omitted than what is explicitly stated. This is in part due to the fact that democracy, unlike inclusive education, has never been the explicit topic of public controversy. Thus, when the democratic principles of the 1970s were abandoned during the 1990s, democracy as an educational objective remained intact, though only as a dead letter. Official educational policy was silent about things that one should expect to be central to democratic educational policy such as equality, gender, and class. This has been pointed out by Jóhannesson (2006):

The conjuncture of the vision of inclusion, the technological approach to defining differences, and the market-oriented approach in financing education (e.g., management by results) creates a silence about equality in other terms, such as gender, residence, class, and culture. (p. 114)

The final thing I want to point out concerning background ideas or discursive patterns relating to democratic and inclusive education is that the two are by 
and large considered to be distinct fields. Although inclusive education and democracy as educational policy can both be traced back to the School Act of 1974 the two have not been thought of as part and parcel of the same ideal. This may perhaps be explained by such down-to-earth factors as school financing (Jóhannesson, 2006). Debates about inclusive education - or tensions between inclusive education and special education - tend to revolve around (a) systems of aid for specific groups of students (diagnosed with specific conditions) rather than general pedagogical practices; $(b)$ the distribution of limited resources such as welfare provisions rather than things that are owed the individuals as matters of basic rights; and (c) the role of schools as preparation for what awaits the students once they move on to the next school level and, finally, to the job market.

\section{Different ideologies of schools and education}

The above view of democratic and inclusive education runs contrary to strong currents in scholarship and advocacy on inclusion and disability exemplified by, for instance, the Salamanca declaration from 1994 and the World Report on Disability from 2011(WHO, 2011). It also runs contrary to recent academic work in the field of inclusive education (Allan, 2003, 2008; Jóhannesson, 2006; Jónsson, 2011; Slee, 2011). Considering inclusive education as an essentially democratic requirement that ought to permeate school practices means that inclusion must be taken as a fundamental value, both political and educational. And here one encounters differences among teachers, parents, and scholars alike which are both deeply rooted and have widespread implications. The differences are not simply about the effectiveness of certain methods or some practical matters but are best described as ideological differences about education and schooling in general.

A dominant ideology is a collection of ideas, prejudices, and conceptions of the world in virtue of which people look at and think about society, social institutions, their surroundings, other people, and themselves. Ideology in this sense is not explicitly expressed, neither by certain individuals nor by any group of people, but is exemplified by what people say and do, and what they don't say or do. It may be difficult to articulate or even recognize because the dominant ideology constitutes, at any time, the obvious - it is 'common sense' - though in retrospect it is often all but that (Zizek, 1997). Foucault (1984) puts the point well when discussing the sources of his work on psychiatry and medicine:

There were no ready-made concepts, no approved terms of vocabulary available for questions like the power effects of psychiatry or the political function of medicine ... The price Marxists paid for their fidelity to the old positivism was a radical deafness to a whole series of questions posed by science. (pp. 52-53)

Ideology is also implicit in the institutional structures that are found in society, not least in schools where it is shown by what is counted as normal functioning of those institutions.

Ideological differences, although general in character, generate conflicts in the everyday work of teachers who feel pulled in different directions (Bjarnason \& Gunnpórsdóttir, 2014). Many teachers experience frustration and when things are at their worst, school may turn into a territory of failure (Allan, 2008) - for students and teachers alike. 
Conceiving of the frustrations in the field of inclusive education as a conflict of ideologies echoes some recent trends in the related field of disability studies. In an editorial to a special issue of the International Journal of Inclusive Education, recent trends in the field of disability studies are described in the following way:

Gabel \& Peters (2004) acknowledged that the social model is explanatory, but insufficient for creating change. To move forward, they suggested the use of resistance theory to comprehend the intricate and multifaceted relationships, interactions, and negotiations among divergent ideas, while simultaneously bringing together the global community in pursuit of praxis. (Connor et al., 2008, p. 443)

Though Gabel and Peters (2004) do not describe their approach in terms of conflicting ideologies - and may narrow the focus too much by using the word 'paradigm' - they come close to this when writing:

\begin{abstract}
Thinking of resistance in this way, as operating in all directions of the social sphere and across paradigmatic boundaries, helps one to understand the push and pull of the conversation of resistance. Resistance functions as a way for disabled people to push against dominance while also attempting to pull society into disabled people's way of seeing. (p. 594-595)
\end{abstract}

The resistance described here does not stem from nuances between competing views of specific professionals, but from a conflict of ideas about what is a normal function of a social system. In the field of inclusive education similar conflicts concern ideas about what are the normal workings of schools, what institutional structures are legitimate, and to what kind of authority students can be subjected. Recent trends in inclusive education have emphasized human diversity and the demands of justice and democracy in general, not only for disabled students, but also for the very bright, the non-native speaking, the poor, and the very shy (Guðjónsdóttir \& Karlsdóttir, 2010).

\title{
4. Ideology and the medical gaze
}

Foucault's concept of the medical gaze can be illuminating when discussing ideological presuppositions for inclusion and democracy. In the introduction to Reassessing Foucault: Power, Medicine and the Body, Jones and Porter (1994) write:

[Foucault] was fascinated by the conventions of the medical 'gaze' for eliciting truth; the production of symptoms and signs within determinate frameworks of signification: the vital role of technologies of power and specific institutional settings (diagnostic tests, hospitals, asylums); and not least the capacity of medical power to be - or appear to be - positive and benign rather than oppressive, and to create 'subjects' in both senses of the term: clients subjected to protocols of power, but also specific individuals (everyone has, for example, his or her own unique medical history or fingerprint). (p. 11)

As noted above, discourse about inclusive education has been individualistic, medical, and technical and premised on education as a market commodity. Students with special educational needs are accordingly identified as having 'symptoms and signs within determinate frameworks of signification' and although the treatment these students receive is portrayed as benign - and certainly may have various good consequences - it subjects them to power 
which has little or no commitment to democratic principles nor need it be sensitive to the socio-economic conditions of the students. The latter is observed by Jóhannesson (2006) while examining policy documents from the late 1990s.

... because clinical methods have become the way to deal with special educational needs, they must be treated as individual differences; clinical psychology or medicine cannot properly deal with cultural differences or gender differences. This means that only individual differences are acknowledged, thus side-lining differences that may arise in terms of culture or the socio-economic circumstances of the children. (p. 115)

The medical gaze is not only relevant when considering treatment of 'diagnosed' special educational needs but extends to the conception of the child itself, as noted by Bjarnason (2008):

\begin{abstract}
Medical staff, trained to alleviate suffering and prevent harm, tend to favour screening and the termination of pregnancy when the fetus is found to be impaired. Prospective parents are more than likely to share this view owing to the widespread acceptance of the medical perspective. Such prospective parents are likely to take upon themselves the suffering of abortion to save their future child and the family from suffering, stress, and harm, and to prevent the unborn fetus the loss of future opportunities. (p. 266)
\end{abstract}

Bjarnason (2008) then refers to Foucault's notion of medical gaze to contextualize the above observation:

[The medical gaze] implies the power the medical professionals gain over their patients when they denote the often-dehumanizing method of separating the patients' body from the person in diagnosis and treatment. This term [medical gaze] captures some of the greater social issues involved that reify the impaired fetuses as 'a social artifact' and how that is communicated to parents-to-be who themselves are placed under the gaze as patients. (p. 269)

The medical gaze constitutes an element of the dominant educational ideology. However, it is not something people deliberately accept or defend, but figures as a legitimizing principle and structuring force in both institutional design and personal interaction. The medical gaze is also evident in much research on deviant children or deviant child behaviour, where the children themselves, as persons with complex lives in a socio-economic setting, fade out of sight - or become 'a social artifact' - with the researchers gaining power by defining what is legitimate or deviant behaviour and what constitutes a deviant child as opposed to a normal one. The focus becomes predefined deviation and the means of either managing it directly or modifying antecedent behaviour that has been found to correlate with future behaviour defined as deviant (Kazdin, 1980; lalongo et al., 1999).

\title{
5. Inclusion and democracy as tasks for schools
}

Different conceptions of democracy not only entail different roles for schools as institutions in a democratic society, but they also entail different conceptions of what makes school practices democratic. An underlying idea in the conception of democracy that I described above is that social affairs should be organized 
as a free and open competition among people for preferences, positions, and various other social as well as personal goods. It is granted that people have different views, needs, and preferences, and democratic institutions are then designed to ensure a free market of ideas and opinions and competition free of coercion and monopoly to accommodate this diversity. This conception of democracy has been labelled 'aggregative democracy' (Young, 2002, pp. 1822).

The democratic role of the school, in this view, is mainly twofold. First, it is to make people fit to participate in the market of ideas and, secondly, to ensure knowledge of fundamental rights and basic principles that are needed for society to function efficiently. In this view, the role of the school is to prepare students for a society to which they do not yet belong, in much the same way as the school serves to prepare students for the workplace. Here we see the technical, individualistic, and neo-liberal aspects of the dominant ideology of education. Democracy becomes a task for the schools or even a problem; it is something that schools face and must solve however successfully, just as they must produce knowledgeable and skilled workers for the workplace (Biesta, 2006). But democracy as a problem for schools may be impossible to solve as Keith Ballard (2003) observes, drawing on work by Paul James:

\begin{abstract}
James ... says that in the fragmented, individualized and globalized world of New Right liberal economics, the 'sociality of identity' is being lost.... In part, this is because the concept of a society is challenged, and replaced with the idea that only the 'personal and familial' ... has meaning. In this context, rather than recognizing and valuing our dependencies and interdependencies, which would seem to be central to the notion of an inclusive society, the term dependent is constructed as involving a 'lesser person,' one who cannot, or will not, fend for themselves ... (p. 11)
\end{abstract}

\title{
6. Democratic character and transgression
}

The aggregative view of democracy is often contrasted with a deliberative conception (Bohman \& Rehg, 1997). Most theories of deliberative democracy focus primarily on structure and policy and on the making of collective decisions, premised on the mutual benefit of people who live together as equals and who have joined forces in a free association (Cohen, 1997; Gutmann \& Thompson, 2004). Proceeding from these premises, one faces difficult problems when applying a theory of deliberative democracy to schools where (a) the individuals involved do not come together as equals but as unequal in important respects (teacher/student, headmaster/teacher), (b) are not there for mutual benefit, and (c) part of the population, namely, the students, has no choice but to participate irrespective of experience or preferences.

Considering the diversity of the students, both psychological and socioeconomic, the deliberative model lacks an account of the role of attitudes and practices that are essential for sustaining and cultivating just and democratic functions, while at the same time being central for transforming the school into a truly educational setting; a learning community in the sense of bell hooks (1994). However, such a concept of democracy and education was argued for by John Dewey (1916) 100 years ago. Despite important similarities between Dewey's conception and the deliberative tradition there are also important differences between the two, the most important of which have to do with Dewey's starting point. In a speech from 1939, 'Creative democracy - the task before us', he states: 
Instead of thinking of our own [democratic] dispositions and habits as accommodated to certain institutions we have to learn to think of the latter as expressions, projections and extensions of habitually dominant personal attitudes. (Dewey, 1998 [1939], p. 341)

The common way of applying a theory of democracy to school practices is by beginning with a notion of democracy as a system of government or means of making collective, binding decisions and then adapting it to the circumstances in the school. Dewey, on the other hand, insists that the starting point should not be a theory of institutional structure or procedural design but 'habitually dominant personal attitudes' ( $p$. 341). It is here where Foucault's idea of transgression becomes helpful. In 'A preface to transgression' (1977), Foucault says:

Transgression is an action which involves the limit, that narrow zone of a line where it displays the flash of its passage, but perhaps also its entire trajectory, even its origin; it is likely that transgression has its entire space in the line it crosses. (pp. 33-34)

A little later, Foucault (1977) reflects on the interdependence of the limit and transgression:

The limit and transgression depend on each other for whatever density of being they possess: a limit could not exist if it were absolutely uncrossable and, reciprocally, transgression would be pointless if it merely crossed a limit composed of illusions and shadows. (p. 34)

It is important to note here that when talking about transgression, Foucault is not envisaging a world without distinctions - without class, gender, roles such as student/teacher, and so on - but is opening up a way of seeing the distinctions as dynamic and not defining of their constituent elements. Transgression means that the relevant distinctions are as much a potential for a new being as they are definitive of being itself. Thus, he writes:

Transgression, then, is not related to the limit as black to white, the prohibited to the lawful, the outside to the inside, or as the open area of a building to its enclosed spaces. Rather, their relationship takes the form of a spiral which no simple infraction can exhaust. (Foucault, 1977, p. 35)

Julie Allan (2011) has applied the notion of transgression to disability research where she has observed students with disability. She writes:

Transgression, the practical and playful resistance to limits ... is an important way for people with disabilities to challenge the disabling barriers they encounter. Transgression is not antagonistic or aggressive, nor does it involve a contest in which there is a victor; rather, it allows individuals with disabilities to shape their own identities by subverting the norms that compel them to repeatedly perform as marginal. (p. 154)

This idea of challenging barriers and subverting norms that compel students to perform as marginal can be applied more widely to a theory of democratic education and, I shall argue, one can see this as a central feature of a Deweyan conception of democracy. Dewey's way of framing his ideas is different from that of Foucault, and I do not want to hint at any general agreement between the two. My point here is simply that Foucault's conception of transgression can be used to shed light on Dewey's idea of democracy and, likewise, Dewey's 
ideas of democracy can help us see the relevance of the concept of transgression for democratic education quite generally.

To move forward in this direction it is important to situate Foucault in the Kantian tradition - as he himself readily did. As Mark Olssen (2006) writes:

\begin{abstract}
Foucault ... situates his own work within the critical tradition of Kant. This tradition, says Foucault, entails 'an analysis of the conditions under which certain relations of subject and object are formed or modified' and a demonstration of how such conditions 'are constitutive of a possible knowledge'. (pp. 246-247)
\end{abstract}

The process of education and its 'possible knowledge' is a constant play on the relations between subject and object. But possible knowledge for Foucault is not simply possible propositional content (as it may have been for Kant) but also possible ways of knowing where the body is as relevant as the cognitive powers, and where feelings and emotions are as relevant as propositional knowledge. Foucault would also include considerations about who is recognized as a knower and the various power relations that come with such recognition.

We only know the limits of possible knowledge by reflecting on actual knowledge. Here, transgression is relevant as a means of challenging and expanding these limits. However, for an educational setting to be genuinely free and democratic, no individual nor any specific group of individuals (be it adults, teachers, 'the experts', et al.) may have an authority on where these limits lie. Thus, in democratic education, the very process of education must be open to creative challenges, not only the ordinary challenges to claims of knowledge one might see in a scientific debate, but also to challenges that constitute transgression of categories which define who someone is, what is appropriate for such a person, and where such a person belongs.

An illuminating description of a transgression in this sense is 'On Being a Cripple' by Nancy Mairs (1986). In this essay Mairs deliberately chooses the label 'cripple' for herself, for she finds that it describes her condition better than labels such as 'disabled' or 'handicapped'. Mairs embraces the label while, at the same time, she rejects the ideological baggage that comes with it by being in charge of her own life as a cripple.

\footnotetext{
People - crippled or not - wince at the word 'cripple,' as they do not at 'handicapped' or 'disabled.' Perhaps I want them to wince. I want them to see me as a tough customer, one to whom the fates /gods /viruses have not been kind, but who can face the brutal truth of her existence squarely. (Mairs, 1986, p. 9)
}

In an educational setting the most basic defining categories are that of subject and object, categories which ought not to be fixed although much of the institutional educational structure is precisely designed for fixing them. Disabled students, as well as students of colour in many parts of the US (see e.g., bell hooks, 1994), and poor students or shy students, students portrayed as having special educational needs, or students showing deviant behaviour are commonly denied the possibility to be subjects in their own lives (Jørgensen, 2004). Such students are constantly the object of this or that programme, steered into this or that direction, being modified for this or that end, none of which are of their own choice. Not only are they compelled to repeatedly perform as marginal', as Allan notes (Allan, 2011, p. 154), but they are also denied the ability, within the educational process, to pass judgement on what they find interesting and what counts as relevant, fair, or worthy of knowing. In 
short, intellectual authority is handed to them from the teachers (with the medical gaze) or from textbooks. None of this is confined to disabled students or students who are marginal or deviant for some reason or another but applies to the whole category of the student. In the introduction to her book Teaching to Transgress (1994), bell hooks writes:

School was the place of ecstasy - pleasure and danger. To be changed by ideas was pure pleasure. But to learn ideas that ran counter to values and beliefs learned at home was to place oneself at risk, to enter the danger zone. Home was the place where I was forced to conform to someone else's image of who and what I would be. School was the place where I would forget that self and, through ideas, reinvent myself. (p. 3)

School is a place for transgression for hooks - a learning community which urges students 'to open [their] minds and hearts so that [they] can know beyond the boundaries of what is acceptable, so that [they] can think and rethink, so that [they] can create new vision' (hooks, 1994, p. 12). This kind of learning community is one which, according to hooks, makes education the practice of freedom. It is this connection between learning, transgressing boundaries, and freedom that must be at the centre of any theory of democratic education, that is, education opposed to coercion into predetermined forms of knowing and being.

Going back to Dewey (1998 [1939]), we can see how he identifies learning as a central element in the democratic process, emphasizing both its cognitive and emotional aspects:

[...] democracy as a way of life is controlled by personal faith in personal day-by-day working together with others. Democracy is the belief that even when needs and ends or consequences are different for each individual, the habit of amicable cooperation - which may include, as in sport, rivalry and competition - is itself a priceless addition to life. To take as far as possible every conflict which arises - and they are bound to arise - out of the atmosphere and medium of force, of violence as a means of settlement into that of discussion and of intelligence is to treat those who disagree even profoundly - with us as those from whom we may learn, and in so far, as friends. (p. 342)

Dewey does not describe democracy as a way of managing differences - or providing means for making decisions in the face of differences - but as a way of living with other people with whom one may disagree. Fundamental to the democratic way of living is the ability to approach other people not only rationally but also emotionally - as friends, as he says, and as people from whom one may learn. Dewey thought of democracy as rooted in personal attitudes and habits - democratic character or moral virtue, one could say - arguing that institutions are democratic only in so far as they can be seen, in their day-today functioning, as being projections of democratic character.

Dewey may overstate the point when using the word 'friend', since from the perspective of society, friendship as a basis for democracy is too strong a demand. However, we can maintain his insight, for what is needed may not be friendship but respect. The point is not simply that respect will make society better, but that without respect for each other the social relations among the citizens will be cast into a competitive mould and living in a society will be a struggle - a fight for one's own interests - and not a life of mutual learning among people. 
Central to most contemporary thinking about democracy and justice is an acceptance of pluralism and a rejection of independent authority on moral and political issues. Rawls (2001) takes 'reasonable pluralism' as his starting point, and Sen (1992) and Nussbaum (2006) go even further in their insistence on the acceptance of profound diversity, not only in opinions and philosophies of life but also in capabilities. The French philosopher Chantal Mouffe (2000) goes further still, insisting that theorizing about democracy and justice must not only accept pluralism and diversity but has to recognize actual disagreements and conflicts as a basic social condition. A theory of democracy, according to her, is a theory about how to live justly in a society that is marked by such social realities. I think she is right, and I also think that any such theory must include within its scope an account of personal, democratic attitudes in much the same way as Dewey (1916; 1998 [1939]) argued for. Moreover, democratic education in this sense will be an education for transgression along the lines of Foucault and bell hooks, helping people to face the truth of their existence squarely, to use the Mairs's words, whether it is brutal or not. This requires that students be subjects in their own lives and not mere objects of formation. It also requires that students be given both the opportunity and ability to define and redefine who they are and how they are. The deviant child must be on board from the beginning, not as an afterthought or a case for concern, but as an individual facing his or her own reality.

\section{Transgression and Icelandic educational reality}

Reflecting on Icelandic educational reality from the point of view of transgression and democratic education, one can observe both positive and negative aspects. On the positive side, there is high enrolment of students in general compulsory schools; less than one per cent attend special schools (Sigurðardóttir et al., 2014, p. 103). Moreover, data from 2012 shows that around a quarter of all students in the compulsory school receive special support (Menntavísindastofnun, 2014, p. 16); this support is often provided in the classroom, although there is no clear data on this. But on the negative side, the system relies heavily on a medical model view of learning difficulties, with formal diagnosis (usually carried out by the State Diagnostic and Counselling Centre) being a precondition for extra funding and, consequently, increasing the 'need' for diagnoses instead of turning to pedagogical responses. Accordingly, Sigurðardóttir, et al. observe that disabled students are often not included except in a superficial way:

\footnotetext{
However, the location of students with disabilities within the mainstream schools does not mean that they are included or acknowledged as participants in the school life. Participation has not been measured generally in Iceland, but authors of a recent study of the education of mentally disabled students [Marinósson, 2007] concluded that the ground rules were that the school is still considered a 'normal' place where all major deviations were considered problems in need of 'fixing'. (Sigurðardóttir et al., 2014, p. 103)
}

Shortcomings do not only affect disadvantaged students but also extend to educational practices quite generally. The dominant way of teaching is direct lecturing by teachers followed by students working with textbooks and predefined assignments (Óskarsdóttir, 2014). And even though changes towards more open spaces, wider cooperation among teachers, more thematic work, and a move towards a professional learning community (Sigurðardóttir, 2010) have had positive influence on educational practices, teacher-centred 
educational authority is rarely challenged (Jónsson, 2015). Students are given little opportunity to influence the work, to contribute to the formation or transformation of values and goals, and to exercise their own critical and creative abilities. Their inclusion in the process of education is shallow and there is little sign of students transgressing the line between being objects of formation and subjects in their own lives. This is not without exceptions, as, for instance, Hanna Ragnarsdóttir and Börkur Hansen have observed, documenting the development of a collaborative school culture in an inner city school in Reykjavík (Ragnarsdóttir \& Hansen, 2014).

The progressive changes in the 1970s and early 1980s in Iceland opened up spaces for students to be more involved in the process of education, relating it closer to their own reality by curriculum amendments and the writing of new teaching material (Edelstein, 2013). This movement never got to the point of what one might call transgressional education, and it is difficult to say how things would have evolved if the whole project had not been cut short in the mid-1980s. During the 1990s and the first decade of the twenty-first century, the whole educational system moved away from democratic education, with increased emphasis on standardized tests and a technical view of education. A new national curriculum in 2011 aimed at a return to democratic principles in education. How it will fare in the long run is still unclear but, as things are today, it seems that schools are preparing students for a predefined future rather than setting them on a journey of transgression and discovery.

\section{References}

Allan, J. (2008). Rethinking inclusive education: The philosophers of difference in practice. Dordrecht: Springer.

Allan, J. (Ed). (2003). Inclusion, participation and democracy: What is the purpose? Dordrecht: Kluwer.

Allan, J. (2011). Complicating, not explicating: Taking up philosophy in learning disability research. Learning Disability Quarterly, 34(2), 153-161.

Ballard, K. (2003). Including ourselves: Teaching, trust, identity and community. In J. Allan (Ed.), Inclusion, participation and democracy: What is the purpose? London: Kluwer.

Barnett, R. (2003). University in a fluid age. In R. Curren (Ed.), A companion to the philosophy of education (pp. 561-568). Oxford: Blackwell Publishing.

Biesta, G. J. J. (2006). Beyond learning: Democratic education for a human future. Boulder CO: Paradigm Publishers.

Bjarnason, D. S. (2008). Private troubles or public issues? The social construction of 'the disabled baby' in the context of social policy and social and technological changes. In S. L. Gabel \& S. Danforth (Eds.), Disability and the politics of education: An international reader (pp. 251-274). New York: Peter Lang Publishing.

Bjarnason, D. \& Gunnpórsdóttir, H. (2014). Conflicts in teachers' professional practices and perspectives about inclusion in Icelandic compulsory schools. European Journal of Special Needs Education, 29(4), 491-504. 
Bjarnason, D. S. \& Marinósson, G. L. (2015). Salamanca and beyond: Inclusive education still up for debate. In F. Kiuppis \& R. Sarromaa Hausstätter (Eds.), Inclusive education: Twenty years after Salamanca (pp. 133-144). New York: Peter Lang.

Bohman, J. \& Rehg, W. (1997). Deliberative democracy. Cambridge MA: MIT Press.

Cohen, J. (1997). Deliberation and democratic legitimacy. In J. Bohman and W. Rehg (Eds.) Deliberative democracy (pp. 67-91). Cambridge MA: MIT Press.

Connor, D. J., Gabel , S. L., Gallagher, D. J. \& Morton, M. (2008). Disability studies and inclusive education - implications for theory, research, and practice. International Journal of Inclusive Education, 12(5-6), 441-457.

Dewey, J. (1916). Democracy and education. New York NY: MacMillan.

Dewey, J. (1998 [1939]). Creative democracy - The task before us. In L.A. Hickman \& T.M. Alexander (Eds.) The essential Dewey, Vol. I (pp. 340-343). Bloomington: Indiana University Press.

Edelstein, W. (1988/2013). Markmið og bygging samfélagsfræðinnar. [Aims and structure of sociology]. In L. Guttormsson (Ed.), Sögukennsluskammdegið Rimman um sögukennslu og samfélagsfræði 1983-1984 (pp. 49-98). Reykjavík: University of Iceland Press.

Foucault, M. (1984). Truth and power. In P. Rabinow (Ed.), The Foucault reader (pp. 51 75). New York: Pantheon Books.

Foucault, M. (1977). Language, counter-memory, practice: Selected essays and interviews. Ithaca, NY: Cornell University Press.

Gabel, S. L. \& Peters, S. (2004). Presage of a paradigm shift? Beyond the social model of disability toward resistance theories of disability, Disability and Society, 19(6), 585-600.

Guðjónsdóttir, H. \& Karlsdóttir, J. (2010). Hvernig látum við púsund blóm blómstra? Skipulag og framkvæmd stefnu um skóla án aðgreiningar. [How do we make a Thousand Flowers Bloom? Organization and Implementation of Inclusive School Policy.] Ráðstefnurit Netlu - Menntakvika 2010.

Gutmann, A. \& Thompson, D. (2004). Why deliberative democracy? Princeton: Princeton University Press.

hooks, b. (1994) Teaching to transgress. New York/London: Routledge.

lalongo, N. S., Werthamer, L., Kellam, S. G., Brown, C. H., \& Wang, S., Lin, Y. (1999). Proximal impact of two first-grade preventive interventions on the early risk behaviors for later substance abuse, depression, and antisocial behavior. American Journal of Community Psychology, 27(5), 599-641.

Jóhannesson, I. Á. (2006). "Strong, independent, able to learn more ...": Inclusion and the construction of school students in Iceland as diagnosable subjects. Discourse: Studies in the cultural politics of education, 27(1), 103-119.

Jónsson, Ó. P. (2011). Lýðræði, réttlæti og menntun. [Democracy, justice and education]. Reykjavík: University of Iceland Press.

Jónsson, Ó. P. (2014). Lýðræð̋isleg menntastefna: Sögulegt ágrip og heimspekileg greining. [Democratic educational policy: Brief history and philosophical analysis]. Icelandic Review of Politics and Administration, 10(1), 99-118.

Jónsson, Ó. P. (2015). Pverstæðan um lýorææðislegt skólastarf. [The paradox of democratic school practices]. Uppeldi og menntun, 24(2). 
Jones, C. \& Porter, R. (1994). Reassessing Foucault: Power, medicine and the body. London: Routledge.

Jørgensen, P. S. (2004). Childrens' participation in a democratic learning environment. In J. MacBeath \& L. Moss (Eds.), Democratic learning: The challenge to school effectiveness (pp. 113-131). New York: Routlege Falmer.

Kazdin, A. E. (1980). Acceptability of alternative treatments for deviant child behavior. Journal of Applied Behavior Analysis, 13(2), 259-273.

Mairs, N. (1986). Plaintext. Tucson, AZ: University of Arizona Press.

Marinósson, G. L. (Ed.). (2007). Tálmar og tækifæri. Menntun nemenda með proskahömlun á Íslandi [Barriers and opportunities: education of disabled pupils in Iceland]. Reykjavík: University of Iceland Press.

Marinósson, G. L. \& Bjarnason, D. S. (2015). Special education today in Iceland. In A. F. Rotatori, J. P. Bakken, S. Burkhardt, F. E. Obiakor, \& U. Sharma (Eds.). Special Education International Perspectives: Practices Across the Globe (Advances in Special Education, Volume 28) (pp. 271-309). Bingley: Emerald Group Publishing Limited.

Menntavísindastofnun Háskóla Íslands. (2014). Greining á gögnum um sérkennslu frá Hagstofu Íslands [Analysis of data from Statistics Iceland]. Reykjavík: Menntavísindastofnun.

Molnar, A. (2005). School commercialism: From democratic ideal to market commodity. New York: Routledge.

Mouffe, C. (2000). Deliberative democracy or agonistic pluralism. Vienna: Institute for advanced studies.

Nussbaum, M. (2006). Frontiers of justice: Disability, nationality and species membership. Cambridge, MA: Harvard University Press.

Olssen, M. (2006). Foucault and the imperatives of education: Critique and self-creation in a non-foundational world. Studies in Philosophy and Education, 25(3), 245271.

Óskarsdóttir, G. G. (2014). Starfshættir í grunnskólum. við upphaf 21. aldar. [Practices in schools at the beginning of the $21^{\text {st }}$ century]. Reykjavík: University of Iceland Press.

Ragnarsdóttir, H \& Hansen, B. (2014). The development of a collaborative school culture: The case of an inner-city school in Reykjavík, Iceland. In H. Ragnarsdóttir \& C. Schmidt (Eds.) Learning spaces for social justice: International perspectives on exemplary practices from preschool to secondary school (pp. 76-92). Sterling: Trentham Books.

Ragnarsdóttir, H. \& Schmidt, C. (Eds.). (2014). Learning spaces for social justice: International perspectives on exemplary practices from preschool to secondary school. Sterling: Trentham Books.

Rawls, J. (2001). Justice as fairness. Cambridge MA: Harvard University Press.

Salamanca statement and framework for action on special needs education. (1994). Salamanca, June 7-10.

Sen, A. (1992). Inequality reexamined. Cambridge MA: Harvard University Press.

Sigurðardóttir, A. K. (2010). Professional learning community in relation to school effectiveness. Scandinavian Journal of Educational Research, 54(5), 395-412. 
Sigurðardóttir, A. K., Gujónsdóttir, H. \& Karlsdóttir, J. (2014). The development of a school for all in Iceland: Equality, threats and political conditions. In U. Blossing et al. (Eds.), The Nordic education model: 'A School for All' encounters neo-liberal policy (pp. 95-113). Dordrecht. Springer.

Slee, R. (2011). The irregular school. Exclusion, schooling and inclusive education. London: Routledge.

WHO. (2011). World report on disability. Geneva: WHO Press.

Young, I. M. (2002). Inclusion and democracy. Oxford: Oxford University Press.

Zizek, S. (1997). The plague of fantasies. London: Verso. 